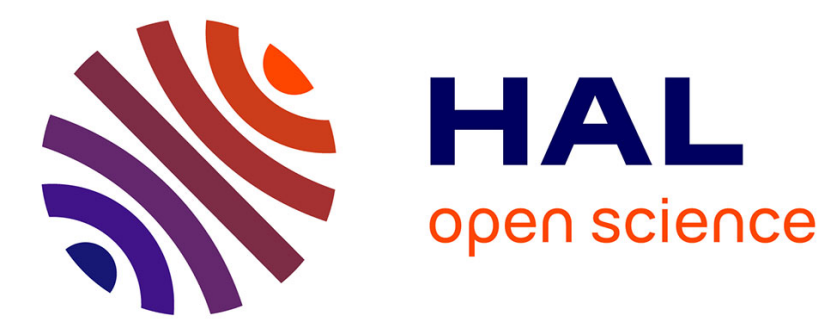

\title{
Arcticness: power and voice from the north,
}

Marine Duc

\section{To cite this version:}

Marine Duc. Arcticness: power and voice from the north,. The Polar Journal, 2018, 8 (1), pp.219-222. 10.1080/2154896X.2018.1478616 . hal-02289549

\section{HAL Id: hal-02289549 \\ https://hal.science/hal-02289549}

Submitted on 16 Sep 2019

HAL is a multi-disciplinary open access archive for the deposit and dissemination of scientific research documents, whether they are published or not. The documents may come from teaching and research institutions in France or abroad, or from public or private research centers.
L'archive ouverte pluridisciplinaire HAL, est destinée au dépôt et à la diffusion de documents scientifiques de niveau recherche, publiés ou non, émanant des établissements d'enseignement et de recherche français ou étrangers, des laboratoires publics ou privés. 
Book review: Arcticness. Power and Voice from the North, by Ilan Kelman (ed.), University College London Press, 184pp., (open-access PDF), ISBN: 978-1-78735-013-7

Marine Duc

UMR 5319 Passages, Departement of geography, Université Bordeaux-Montaigne, Pessac, France

Maison des Suds

12, esplanade des Antilles

33607 Pessac Cedex

France

marine.duc@enrs.fr // +33642949773

$1^{\text {st }}$ year $\mathrm{PhD}$ candidate in geography

http://www.passages.cnrs.fr/spip.php?article496 


\section{Arcticness. Power and Voice from the North, by Ilan Kelman (ed.), University \\ College London Press, 184pp., (open-access PDF), ISBN: 978-1-78735-013-7}

The wide range of contributions makes the last book edited by Ilan Kelman an enjoyable and unexpected work easily accessible due to its open-access availability. Mobilizing arts as well as engineering, glaciology or anthropology, it aims at studying "Arcticness", understood as "the quality of being artic" (p.v). Ilan Kelman is a reader in Risk, Resilience and Global Health at the University College of London (UCL) and researcher at the university of Agder in Norway. He has been joined by $28 \mathrm{PhD}$ candidates, experimented researchers but also experts and artists to create Arcticness. Power and Voice from the North. After a preface written by Ingrid Melby (teaching fellow in political geography at the UCL) and an editorial introduction by Kelman, it is divided in three parts and composed of thirteen chapters, approaching successively representations of the Arctic, the way of living in a region under rapid changes and some consequences of those phenomena. The publication is well illustrated (pictures, a graphic essay, images from radar datasets, diagrams) throughout the text.

Trying to understand the specificity and the character of the Arctic region is especially relevant in a context of rapid changes when "Arcticness" is constituted as a label. Indeed, the past decades have seen the Arctic come at the forefront of global concern. Global change and its economic and political consequences go beyond the global level and include the regional one: greater interest in resources or in seaways, but also ice melting and consequences for sea level. This growing interest towards Arctic regions finds also a translation into the field of scientific research productions. The body of literature relating to Arctic region has been growing: in twenty years, the number of arctic publications indexed in the Web of Science between 1997 and 2015 has increased by $168 \%$ even though the total number of publications increased by only $64 \%$ during the same period ${ }^{1}$. In short, as Melby wrote by reference to Doreen Massey and John Allen's book ${ }^{2}$ in the preface, "Arctic matters, also to those living far south of the Arctic Circle" (vii). Yet, it still remains rather difficult to identify the very heart of the "Arctic". From romanticized imaginaries of ice to the pushing of the "last frontier" of Western consumerism and industrialization and exotic view of Arctic peoples, all of those representations are producing an ontology of the Arctic. At this point, the book is facing the challenge to highlighting the paradox fact that its identity is never identical. Indeed, understanding the features and settings of the Arcticness may help to reveal the power relations at stake about the region: "identifying what, who or where has the 'quality of being Arctic' is high on the agenda; for actors from both near and far [from the Arctic region], their 'Arcticness' becomes a potential asset as they position themselves for Arctic futures" (v).

\footnotetext{
${ }^{1}$ According to Thomson-Reuters Web of Science "Core Collection" (all document types taken between 1996 and 2016 and calculated from a mobile average, answering to the request by "Arctic" as keyword).

${ }^{2}$ Massey, Allen (eds.), Geography matters!

${ }^{3}$ Blangy, Tester, "introduction" (11)
} 
A large range of views are at stake to define Arcticness: it is a cultural object constructed in a relational perspective. In that respect, Ilan Kelman's book displays "northern and non-northern viewpoints" (5) giving a large place to subjectivities. Consequently, and according to the structure, the book can be seen as a mise en abyme: the design of the book comes from the diversity of the Arcticness. The influence of the cultural turn and post-structuralist theories which had impacted social sciences since thirty years are tangible here, especially in regard with subaltern and postcolonial studies. But the wide array of contributions makes the whole volume hard to locate into a specific field, and reinforced by the assumed fact that each of them has the same legitimacy in defining Arcticness.

Getting back in details for each of the three parts is a way to insist on the richness and diversity of the contributions. The first section "Arcticness Emerging" assembles a poem, a comic and a radar data collection in a book published in academic press. While the question of representations and imaginaries of Arctic is a crosswise theme in the whole book, the question is further developed here. It deals with "the making of the beholder" (40) to use the title of Duda's chapter: Arcticness is a matter of who is glancing at the Arctic. For instance, according to Gordon, Arcticness is a personal memory and heritage rediscovered in beading, when the Diakiw's Arcticness is an history made of unequal power relations, where using comics allows to say it sensitively. Beyond those social and diachronic perspectives, another central quality of the Arctic is its unique landscape characterised by the omnipresence of the ice. It is both a frame of living for Arctic people and the reason of a scientifical interest. Using a wide array of diagrams, Tilling (et al.) are introducing what they are doing as glaciologists in the Arctic and how it is shaping their Arcticness. Finally, Duda approaches the concept in a more political point of view. She is showing that the dialectical relation between discourses inside the Arctic and representations from outside - or even sometimes voluntary produced from the inside as the national branding initiatives- could be a support of a regional integration process.

The second part, "Arcticness living", is a step forward into the Arcticness, proceeding by insights of the Arctic peoples' way of living with focus on both human and non-human actors. Surprisingly, it is exclusively composed of contributions from academics and experts, except a poem from Kelman, meanwhile artistic inputs could be relevant here. This section aims at reflecting on the Arcticness in a dynamic perspective, at the crossroads of time(s) and space(s). The rapid changes mentioned above are the background scene of each chapter. Some of the authors highlight characteristics of the Arctic changes by using cases studies and comparison, with a focus on the Arctic resources both traditional and new. As a matter of fact, reindeer herding a land tenure in northern Norway is compared with the evolution of land tenure in Tibet (Naess). More, Van Alstine and Davies are analysing the resource narratives and their connected "multiple imaginaries" (89) both in Ouganda and Greenland. Comparative studies enable the understanding of how Arcticness is shaped as a dialogue between inside and outside the Arctic. We can also mention the valuable contribution of Sellheim, which explores "how legal regimes construe Arcticness" (102) by involving muti-level governance which frames specific Arctic economies. He analyses the marine mammal hunting case, and reaches to the conclusion that the legal frameworks are revealing different representations of Arcticness from the Arctic people themselves: the concept is used here to show that those legal regimes are not taking into account real-life circumstances of Arctic societies. 
"Arcticness futures" focuses on global changes impacts in the Arctic. As the smaller part of the book, it draws on two inquiries and an editorial conclusion. The work of Nadia French (et. al) underlines how Canada and Russia "are reinterpreting their relations with the North" (116) in a context of global change introduced above. However relevant it is to insist on the changes and the evolution of state's discourses about the Arctic, the text can sometimes give a feeling of a programmatic discourse. The other chapter is built as a research note, providing first insights of an on-going and promising research. Emma Wilson, Anne Merrild Hansen and Elana Wilson Rowe are exploring the perceptions of abandoned extractive projects around three case studies in Greenland, Norway and Russia. They use the notion of "unbuilt environments" 4 for that purpose. Bringing together two different articles on terms of framework and data collection and an editorial conclusion, can lead to a lack of structure.

The primary interest of the book is precisely to offer a non-essentialized view of Arcticness. It seems that all the contributors took for granted that it is impossible to define what being Arctic means. They recognize that the risk of essentialization and determinism besides each "-ness" names is too high to produce a single definition. This is probably reinforced by the size and diversity of this region and its inhabitants, often taken as a whole in media discourses. Therefore, the main success of this book is to address the regimes of knowledge production with a focus on the processes of definition more than on the object itself. The goal is not to stop the reflection on the edge of the determination of the parameters of Arcticness, but to approach it as, a product and a construct, made by a set of eyes with an equal legitimacy. Indeed, in terms of defining the meaning of Arcticness, beaded earrings have the same legitimacy as writing poems, measuring sea ice thickness or speaking about the resource frontier. Thus, the identity of the Arctic is firmly subjective and polysemous. This matching idea is precisely developed by Darren Mc Cauley (et al.): "we define Arcticness as a process (rather than a state of being) of bringing voice to those affected by change in the Arctic. It is important not to objectify Arcticness as this will lead inevitably to exclusion" (77). It is how that the original and heterogeneous list of contributions should be read.

The quality of the book might have been even better with a short literature review or a theoretical point on conceptualizing identities to offer a framework to connect chapters among themselves. This literature review would have ensured the consistency and the inputs of this book within the on-going debates. Indeed, others attempts have been made to define close concepts, as "nordicity" or "nordicness" and how they can be distinguished from "arcticness". The idea of branding a construct picture of notherness or arcticness is sometimes evoked, but no mention is done of the work of Christopher Browning about "branding nordicity" who is putting a concept over the construction of the "Nordic exceptionalism" (Browning, 2007) nor how it used as a marketing strategy. Moreover, the founding work of Hamelin about the grades of nordicity used to draw the gradual limits of the North is not mentioned. Hamelin created a set of polar values (1976) to assess the nordicity of a specific space from a set of features. In a spatial perspective, the frame insists on the relational dimension of the nordicity, which could have been a relevant echo to analyse Arcticness. Besides the troubles raised by the concept of "Arcticness" the inherent paradox between a high risk

\footnotetext{
${ }^{4}$ Oberdeck "Archives of the Unbuilt Environment" 251-274; Peyton "Corporate ecology", 359. Even if a project has not been materialized it has a range of effects both in physical environment and perceptions.
} 
of essentialization and fixation of a very mobile concept "by adding -ness to the Arctic, while in fact (...) Arctic is undergoing rapid changes on several fronts" (73) called for a strong theoretical framework. This lack of a strong theoretical introduction can lead to an inventory effect, reinforced by the fact that there is no presentation at all of the sections neither in the editorial introduction nor at the beginning of each part. Some contributions are not well bounded to the book's theme as some acknowledge: " $a$ comparative approach is fruitful for understanding challenges facing reindeer herders in the Arctic parts of Norway. It might not tell us much about the quality of being Arctic" (73).

Finally, despite an overall quality of contributions, one may wonder what is the status of the book. To a certain extent, according to the publisher, and some contributor's status it can be recognized as an academic publication. It is pleasing that the book represents an intellectual risk-taking: it has a strong global meaning as an object of mediation for more or less heard voices of diverse nature, but it is hard to see in which épistémé $e^{5}$ it is situated. The first reason is that the criteria of validity of discourses are not the same for each contribution. Consequently, it rather complex to assess the quality of each contribution regarding the definition of the Arcticness. And secondly, according to the subtitle of the book, "voice and power from the North" it is rather surprising that indigenous voices are often ventriloqued. If the diversity of author's status is high ( $\mathrm{PhD}$ candidates, experimented researchers from various field, artists or experts) we might have expected more works from indigenous peoples to fit closely the subtitle of the book which creates great aspirations in that matter.

\section{References}

TESTER, Frank James, BLANGY, Sylvie. "Introduction: Industrial developement and mining impacts". Etudes inuit. Inuit studies 37, no. 2 (2013) p. 11-14.

BROWNING, Christopher S. "Branding nordicity: Models, identity and the decline of exceptionalism." Cooperation and Conflict 42, no. 1 (2007): 27-51.

HAMELIN, Louis Edmond. Nordicité canadienne (Canadian Nordicity). Montréal: Éditions Hurtubise HMH, 1976.

MASSEY, Doreen et ALLEN, John (ed.). Geography Matters!: a Reader. Cambridge: Cambridge University Press, 1984.

OBERDECK, Kathryn T. "Archives of the Unbuilt Environment: Documents and Discourses of Imagined Space in Twentieth-Century Kohler, Wisconsin." In Archive Stories: Facts, Fictions and the Writing of History, ed. A. Burton (Chapel Hill, NC: University of North Carolina Press, 2006) 251-274.

PEYTON, Jonathan. "Corporate ecology: BC Hydro's Stikine-Iskut project and the unbuilt environment." Journal of Historical Geography 37, no. 3 (2007) p. 358369.

\footnotetext{
${ }^{5}$ Understood in a foucaldian way, as an epistemological field, describing the conditions of possibility of a specific knowledge.
} 